\title{
Bentetthetsmåling under osteoporosebehandling
}

$\emptyset k t$ bentetthet under osteoporosebehandling er assosiert med lavere risiko for fraktur.

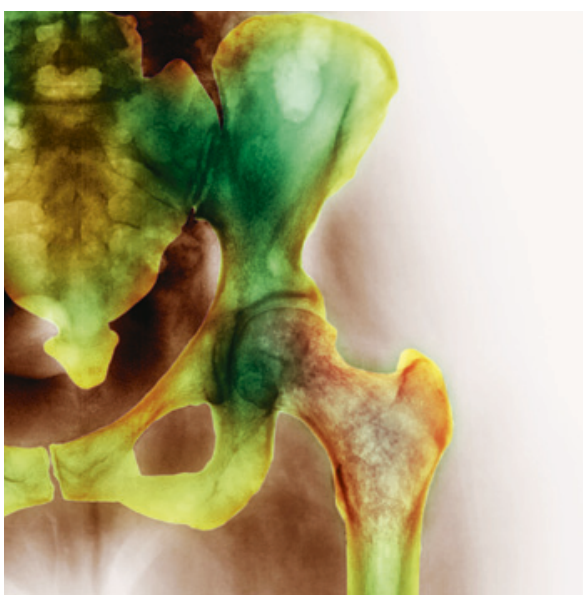

Nedsatt bentetthet hos kvinne i 40-årene. Foto: Science Photo Library
Osteoporose er ofte en medvirkende faktor ved fraktur hos eldre. Selv traumer med relativt lav energi kan gi frakturer når bentettheten er lav.

I en kanadisk studie ble over 6000 kvinner over 40 år inkludert (1). To bentetthetsmålinger ble utført i løpet av median 4,5 år. Ved første måling ble det igangsatt forebyggende medikamentell behandling mot osteoporose. Etter andre måling ble pasientene delt $i$ tre grupper $i$ henhold til resultatene ved siste bentetthetsmåling: økt, uendret eller nedsatt bentetthet. De som hadde økt eller stabil bentetthet hadde henholdsvis 2,6\% (95\% KI 0,7-4,5\%) og 5,5\% (95\% KI $2,8-8,1 \%$ ) lavere risiko for fraktur sammenlignet med kvinner med nedsatt bentetthet.

- Denne studien er relevant for norske forhold, fordi kanadisk og norsk helsevesen er nokså likt organisert, sier Erik Fink Eriksen, som er professor ved Oslo universitetssykehus. - Studien styrker bruken av ben- tetthetsmålinger av hofte i monitorering av behandlingseffekt hos pasienter med osteoporose, men den kan ikke vise hva som er optimalt intervall for slike målinger, sier han.

- I studien ble pasientene behandlet på ulikt vis, de aller fleste fikk bisfosfonater, påpeker Eriksen, som mener at det ville vært interessant å undersøke nytteverdien av endringer i benmarkører også, ettersom endringer $\mathrm{i}$ bentetthet etter antiresorptiv behandling primært er relatert til endringer $i$ benomsetningen.

\section{Kaveh Rashidi}

Tidsskriftet

\section{Litteratur}

1. Leslie WD, Majumdar SR, Morin SN et al. Change in Bone Mineral Density Is an Indicator of Treatment-Related Antifracture Effect in Routine Clinical Practice: A Registry-Based Cohort Study. Ann Intern Med 2016; 165: 465-72.

\section{Akupunktur mot forstoppelse?}

\author{
Akupunkturbehandling kan ha god effekt ved kronisk, alvorlig \\ obstipasjon.
}

Akupunktur blir brukt mot kronisk forstoppelse, men effekten av behandlingen er ikke godt dokumentert. I en kinesisk studie som nylig er publisert i tidsskriftet Annals of Internal Medicine, ble 1075 pasienter med kronisk, alvorlig obstipasjon fra 15 sykehus inkludert (1). De ble randomisert til elektroakupunktur i tradisjonelle akupunkturpunkter eller narreakupunktur i åtte uker og fulgt i 20 uker.

De som fikk akupunktur, hadde i behandlingsperioden i gjennomsnitt 1,76 (95\% KI 1,61-1,89) flere tarmtømminger enn før behandlingen. Kontrollgruppen hadde mindre tarmaktivitet, i gjennomsnittsnitt $0,87(0,73-0,97)$ flere enn før behandlingen. Andelen pasienter som hadde tre eller flere ukentlige tarmtømminger, var omtrent tre ganger så høy i akupunkturgruppen som i kontrollgruppen $(\mathrm{p}<0,001)$

- Det er interessant at vi har her fått en stor, solid studie om bruk av akupunktur ved obstipasjon, sier Arne Johan Norheim, som er professor ved Universitetet i Tromsø. - Den åpne forskningsdesignen innebærer at det kan hevdes at det er systemeffekten som er utforsket og ikke den spesifikke nåleeffekten, sier han.

- I et klinisk perspektiv bør dette likevel ikke tolkes ensidig negativt. Pasientene i studien anga betydelig bedret livskvalitet etter akupunkturbehandlingen. Akupunktur kan derfor være et behandlingsalternativ, også for norske pasienter med funksjonell obstipasjon, sier Norheim.

\section{Kaveh Rashidi}

Tidsskriftet

\section{Litteratur}

1. Liu Z, Yan S, Wu J et al. Acupuncture for Chronic Severe Functional Constipation: A Randomized Trial. Ann Intern Med 2016; 165: 761-9.

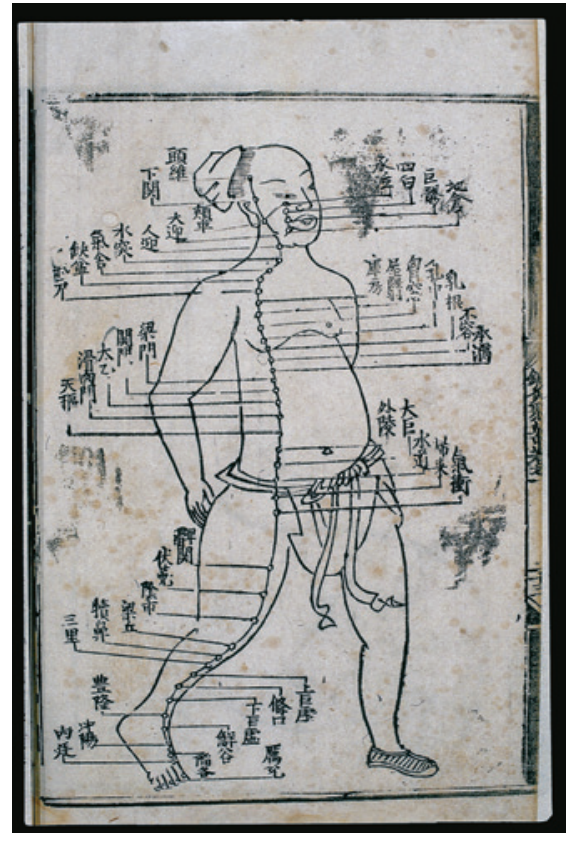

Kinesisk akupunkturkart fra Ming-dynastiet, år 1537 Wellcome Library, London (CC BY 4.0) 